\title{
The Maternité Anglaise: A Lasting Legacy of the Friends' War Victims' Relief Committee to the People of France during the First World War (1914-1918)
}

\author{
Linda Palfreeman
}

Citation: Palfreeman, Linda. 2021. The Maternité Anglaise: A Lasting Legacy of the Friends' War Victims' Relief Committee to the People of France during the First World War (1914-1918). Religions 12: 265. https://doi.org/10.3390/ rel12040265

Academic Editor: Stephen G. Parker

Received: 10 March 2021

Accepted: 6 April 2021

Published: 9 April 2021

Publisher's Note: MDPI stays neutral with regard to jurisdictional claims in published maps and institutional affiliations.

Copyright: (C) 2021 by the author Licensee MDPI, Basel, Switzerland. This article is an open access article distributed under the terms and conditions of the Creative Commons Attribution (CC BY) license (https:// creativecommons.org/licenses/by/ $4.0 /)$
Departamento de Educación, CEU Cardinal Herrera University, 03203 Elche, Spain; palfr.el@uchceu.es
Abstract: After the outbreak of war in Europe in 1914, the British government's call to arms caused a moral and religious dilemma for members of the Religious Society of Friends (Friends or Quakers), whose fundamental principle was (and is) the rejection of war and violence. Many Friends sought means of reconciling their duty to God with their duty to their country, and the prospect of helping to alleviate the suffering of the civilian victims of the fighting provided them with an acceptable alternative. Together with fellow Friend T. Edmund Harvey MP, Dr Hilda Clark set about rallying the support of Friends and sympathisers willing to go out to France to administer humanitarian aid to non-combatants. The committee adopted the name used by the distinguished organisation that had administered relief in the Franco-Prussian War-the Friends' War Victims' Relief Committee (FWVRC). Extensive and multifaceted aid work was carried out in much of northern France by the FWVRC's general relief team. The following essay, however, examines more closely the medical assistance provided under the leadership of Hilda Clark. In particular, it focuses on the maternity hospital created and run by the FWVRC in Châlons-sur-Marne, which became a lasting legacy of the Friends to the people of the Marne.

Keywords: Quakers; First World War; Friends' War Victims' Relief Committee; France; humanitarian aid; medical assistance; maternity hospital

\section{Introduction}

When war broke out in Europe in the summer of 1914, many thousands of Britons clamoured to enlist. Others, for ethical, moral, religious, or humanitarian reasons, believed it to be their duty not to do so. Among these were members of the Religious Society of Friends (n.d.) (Friends or Quakers) whose fundamental principle was (and is) the rejection of war and violence. ${ }^{1}$ Nevertheless, it is also Quaker principle that each individual be led by their own conscience, and a few came to the decision that joining in the fight was justifiable in the exceptional circumstances. ${ }^{2}$ Many Friends, however, sought alternative means of reconciling their duty to God with their duty to their country. Some joined the Red Cross or became members of the voluntary medical team, the Friends' Ambulance Unit. ${ }^{3}$ The latter, however, despite its name, was never an official organ of the Society of Friends, and though it gained the sympathy of many of the Society's members, it was denounced for its (inevitable) collaboration in military affairs. It was not a viable option for all.

1 The full text of the original Quaker declaration of peace is available at http://quaker.org/legacy/minnfm/peace/A\%20Declaration\%20to\%20 Charles\%20II\%201660.htm (accessed on 3 November 2020).

2 A total of 259 Friends enlisted in the Army. Of these, 43 joined the Royal Army Medical Corps and 30 or so became members of the Home Front Militia. There would be heated debate on the issue of enlistment throughout the conflict. For further discussion, see, for example, Rubinstein (2015), A Quaker Dilemma: The Rowntree family and the Great War 1914-1918, York: Quacks Books, 2015.

3 For further information on the work of the Friends' Ambulance Unit, see Palfreeman (2018), 'The Friends' Ambulance Unit in the First World War', Religions (2018) vol. 9, n. 5, art. 165 
Regardless of their stance on enlistment, many Friends were eager to help alleviate the suffering of the civilian victims of the fighting, as the Society had done so remarkably in previous conflicts such as the Crimean War and the South African and Balkan Wars. Prior to the First World War, Friends had been involved in at least twenty-four relief projects of various kinds, including those following five potato famines in Ireland. ${ }^{4}$ However, their most extensive and most notable enterprise was that begun in 1870 during the FrancoPrussian War and later continued in France and Alsace-Lorraine. This set the precedent for the relief work that would be undertaken in 1914 in France and that would afford Friends access to war zones from which other voluntary organisations had been barred by the French authorities.

As the German Army began its invasion of France and Belgium, thousands of people fled their homes, some escaping to Britain at the invitation of the British government. The Friends joined forces with organisations such as the National Union of Women's Suffrage Societies (NUWSS) and the War Relief Commission (WRC), organising voluntary assistance on a massive scale to supplement government aid for the refugees. ${ }^{5}$ The presence of these first refugees to reach Britain also highlighted the plight of the many thousands more homeless civilians trapped in the war zones. American relief worker J. T. Elliott described the Friends' response:

As the tragedy unfolded in the first few weeks of the war, English Friends burned with the desire to do something - anything — to relieve anguish and misery which, it was only too clear, would exist on a scale so appalling as to constitute the supreme call of a lifetime. ${ }^{6}$

One who wasted no time in converting that desire into action was Dr Hilda Clark (1881-1955). Hilda Clark came from a family of strong Quaker women, committed to social reform and the defence of women's rights. Her paternal grandmother was celebrated anti-slavery crusader Eleanor Stephens Clark and her mother, Helen Clark, led national campaigns for improvements in welfare, education, and women's suffrage. She also supported the efforts to gain equality for women within the Society of Friends. ${ }^{7}$

It is of little surprise that Hilda and her sisters Margaret, Esther, and Alice followed in the footsteps of their formidable female forbears. They all became members of the Women's Liberal Federation and of the National Union of Women's Suffrage Societies (NUWSS). Hilda was also a member of the Women's Social and Political Union (WSPU). However, none would take part in the violent protests staged by more extremist suffragette groups led by the Pankhursts. Hilda Clark would employ more subtle and yet more direct means of challenging the myth of male superiority, and the advent of war, as terrible as that would be, would further that cause, as women were accepted (if not totally embraced) into the workforce and into the previously male-dominated professional and political arenas. A crucial factor in Clark's success within this realm, and indeed throughout her life's work, was her religious faith.

One thing I understand [ ... ] is that one's intellect alone won't pull one through, and that the greatest service it can perform is to open a window for that thing that we call the divine spirit. ${ }^{8}$

It was while she was completing her medical training at the Royal Free Hospital, London, in 1908, that Clark met midwife Edith Pye, with whom she would form an

Pearson and Pearson (2015), Friends' Ambulance Unit in World War I and World War II, Friends Historical Library Dublin, 2015, p. ix.

5 For further details, see Grant (2014), Philanthropy and Voluntary Action in the First World War: Mobilizing Charity, (New York: Routledge, 2014) and Roberts (2014), Birmingham: Remembering 1914-1918, (Stroud: The History Press Ltd., 2014).

6 In Charles Evans, 'American Friends' Service Committee, First Annual Report of Charles Evans, Chief of Friends' Unit in France', American Red Cross, 1917, pp. 1-2. While attempting to give a true sense of the Quaker response to the outbreak of war, we cannot ignore the propagandistic nature of such reports, that were motivated, in part, by the need to raise funds among their readership, for the continuation of the relief work in France.

7 Sandra Stanley Holton, Suffrage Days: Stories from the Women's Suffrage Movement, (Routledge 1996, p. 7).

8 Clark's letter to Pye in Edith Pye (ed), War and its aftermath: Letters from Hilda Clark, M.B., B.S. from France, Austria and the near East 1914-1924, (London: Clare, Son \& Co. Ltd., 1956, p. 6). 
inseparable bond. Soon after that meeting, Pye became a member of the Religious Society of Friends and would, alongside Clark, dedicate her life to helping those in need, particularly women and infants suffering in the wake of destruction wreaked by war. They would begin that work, as we shall see, in wartime France. Clark was 33 years old when war broke out, and Pye was 38 .

Together with prominent fellow Friend T. Edmund Harvey MP, Clark set about rallying the support of Friends and sympathisers willing to go out to France and Belgium to administer medical assistance and other aid to non-combatants. The Meeting for Sufferings gave the proposal its full approval, and a committee was appointed to get the work underway. ${ }^{9}$ The committee adopted the name used by the distinguished organisation that had administered relief in the Franco-Prussian War-the Friends' War Victims' Relief Committee (FWVRC).

\section{Methodology}

Considering that the twentieth century is often described as the 'century of refugees' or the 'century of displaced persons', historiography on refugee relief, and the significant part played by women in that relief, is scarce. Among the notable exceptions is Katherine Storr's Excluded from the Record. Storr challenges the traditional notions that 'war is exclusively a male matter, that wartime death and suffering are gender-specific and quantifiable according to the wearing of a uniform, and that courage is an exclusively male attribute called upon in combat'. ${ }^{10}$ Storr also highlights the suffragist-Quaker connection in First World War relief echoed in this particular essay.

A uniquely detailed account of the humanitarian work of the Friends' War Victims' Relief Committee in France during the First World War is A Quaker Adventure, the Story of Nine Years' Relief and Reconstruction. Written by Ruth Fry, General Secretary of the FWVRC, the book is an extremely comprehensive, though somewhat partisan, version of the Committee's extensive wartime and post-war relief activities. ${ }^{11}$ However, FWVRC members were assiduous in their report-keeping, and individual volunteers wrote diaries and memoirs and described events in correspondence with their families and friends. These 'hidden' texts, not intended for publication, offer honest, spontaneous accounts of the day-to-day work that volunteers were doing and on what was going on around them. They reveal moments of fulfilment and frustration, joy and despair. Compared and contrasted with official, 'sanitized' versions of events, they provide greater insight to the exact nature of the FWVRC's undertakings among the citizens of war-torn northern France, as well as into the particular experiences, thoughts, and beliefs of the individual workers who found themselves compelled to volunteer.

The texts in question form part of a broad, though somewhat disperse, body of documentation available today in British archives, such as those of the Imperial War Museum, Friends' House Library, the Cadbury Research Library at the University of Birmingham, and Leeds University's Brotherton Library. Further afield, FWVRC records are housed by the American Friends Service Committee (AFSC), Philadelphia, and the Hoover Institution Archives at Stanford University, California, USA. This essay draws largely upon the reports, diaries, memoirs, and correspondence (both private and official) of members of the FWVRC, held at Friends' House Library, London, and on assorted documentation (official reports and private letters) pertaining to the AFSC, held in the aforementioned archives in California and Philadelphia. In addition, forming a crucial focus of examination is documentation housed in the Archives Departamentales de la Marne, in what is now Châlons-en-Champagne, northeast France. This archive holds papers pertaining to the work carried out there during the war by the FWVRC. This includes

9 In McQuillan (2015), “World War 1 relief and after: Hilda Clark”, in Quaker Connections, Number 64, March 2015: 22. The initial committee comprised T. Edmund Harvey, Roderick R. Clark, E. Harold Marsh, Alfred H. Brow, Dr Hilda Clark, William Arthur Albright, Herbert Corder, Joan M. Fry, Dr Helen Webb, Mary Jane Godlee, Alfred Brooks, Guliana Crosfield, and Edith M. Pye.

10 Katherine Storr, Excluded from the Record: Women, Refugees and Relief 1914-1929, (Bern: Peter Lang, 2010, p. 2).

11 (Fry 1927), A Quaker adventure: the story of nine years' relief and reconstruction, (New York, Frank-Maurice, Inc. 1927). 
what remains of the almost daily correspondence between the prefecture of the region and the administrators of the FWVRC, as well as some letters of thanks from individuals and families for whom they had cared. It is testimony to the very special relationship that developed between the Quaker organisation and the people of France-both authorities and ordinary citizens. The remarkable social media project 'The Whitefeather Diaries', has provided further online access to some of the FWVRC's records held at Friends' House Library. The website was launched to mark the centenary of World War I and, more specifically, to highlight aspects of war hitherto largely ignored: 'resistance to killing and the relief of suffering'.12

The nature of the work to be carried out in France was varied and its extent vast. It would fall into four main categories: (i) general relief work including the provision of food, clothing, and furniture; (ii) the building of prefabricated housing and repair of ruined homes; (iii) agricultural work; and (iv) medical work and nursing. It is the latter category that forms the chief focus of this particular study.

\section{The FWVRC Launches Its Campaign}

Together with subscriptions from individuals and some public funding, the initial target of GBP 3000 to fund the enterprise was almost immediately surpassed. ${ }^{13}$ Although the United States had not yet joined the war, the American Friends' Committee and the American Red Cross also contributed generous sums of money. ${ }^{14}$ By the end of the war, the FWVRC's spending on relief and medical work was practically impossible to compute.

As work increased, the organisation expanded, eventually developing into an enterprise of vast dimensions, operating for over nine years and reaching at least nine European countries. By the end of the war, some 1070 English and 780 Americans formed its workforce abroad, and about 270 more were based at home, in the London office and in the warehouse that the Committee had acquired for the reception, sorting, and distribution of donated goods such as clothing, food, and blankets. ${ }^{15}$ Volunteers were by no means all members of the Society of Friends and came from every social, professional, and political circumstance. In the great majority of cases, they worked on an entirely voluntary basis. ${ }^{16}$ The FWVRC's chief secretary for the duration of the war was Ruth Fry (1878-1962). Her sister, Margery Fry 1 (874-1958), was also heavily involved in the FWVRC's relief work in France. Ruth would later write the history of the FWVRC, A Quaker Adventure. ${ }^{17}$

\section{The Committee Sets Sail for France}

By the time the German Army was stopped in its tracks on the Marne in early September 1914, ${ }^{18}$ it managed to occupy over $95 \%$ of Belgium and caused a great deal of damage and destruction both in Belgium and in eastern France. Coming at a time when crops were about to be harvested, the fighting caused tremendous ruin and consequent suffering. The battle was fought from 6 to 10 September and resulted in an Allied victory against the German armies in the west. Victory, however, came at a cost, especially for those civilians trapped in the war zone. A large part of eastern France lay in ruins, and an even a larger part was occupied by the Germans. With most of their menfolk called to arms, the inhabitants of these areas were now mostly women and children and the old and infirm.

12 The website of the Whitefeather Diaries project: http:/ / www.whitefeatherdiaries.org.uk/about-site (accessed on 11 September 2020).

13 At the time of the Treasury Grant, which gave to approved societies GBP 1 for every GBP 1 collected for certain countries, the Committee received about GBP 24,000 per month from the British government.

14 The French government would also award the FWVRC grants towards the costs of its aid work, as well as giving building materials, petrol for cars, and maintenance costs for the medical facilities it provided.

15 The large warehouse at $22 \mathrm{New}$ Street Square was loaned to the Committee by Messrs. Spottiswoode and Co.

16 Exceptionally, for some doctors and nurses, for example, an honorarium was awarded.

17 (Fry 1927), A Quaker adventure: the story of nine years' relief and reconstruction, (New York, Frank-Maurice, Inc. 1927).

18 The First Battle of the Marne raged from 6 to 12 September 1914. It resulted in an Allied victory against the German armies in the west, bringing to an end the war of movement that had lasted since the beginning of August and marking the beginning of four years of trench warfare. 
On 26 September 1914, at the behest of Hilda Clark, midwife Edith Pye (1876-1965) travelled to Paris, to learn what need there was for medical and nursing assistance. ${ }^{19}$ She was warmly received by Renée de Montmort, founder and honorary secretary of the Association des Infermières Visiteuses de France. De Montmort showed great enthusiasm for Clark's plan to send doctors, nurses, and orderlies into the devastated district to help civilians. Government minister Leon Bourgeois also expressed support for the proposed scheme. Meanwhile, in London, Clark contacted banker Gaston Verdé-Delisle, who was in the capital to organise help for the French Red Cross. Impressed by the Friends' previous history of relief work, Verdé-Delisle became instrumental in securing for them the authorisation of the French Ministry of War. Pye's visit was followed, in early October, by that of T. Edmund Harvey and another small party of Friends, which included George Henry Mennell, his wife, and his brother, Edward Mennell. Together with John Bellows, the Mennell family was the first to undertake relief work in France in September and early October 1914, when they journeyed through the villages near Meaux, distributing clothing and boots. They also obtained recognition from the French authorities for the use of the 'Quaker Star' worn by those Friends who had formed part of the first FWVRC in 1871. While the latter group carried out this initial relief work, Harvey negotiated with the French authorities the more formal undertaking being proposed by the Society. The FWVRC functioned under the auspices of the Association des Infermières Visiteuses de France and was placed under the overall authority of the Santé Militaire. ${ }^{20}$

On 1 November 1914, Renée de Montmort wrote to Hilda Clark from Paris: ‘Our negotiations have at last been wholly successful [ ... ] The expedition will very probably be able to begin active work in the Marne district by Monday next. ${ }^{21}$ The first team set out for France just a few days later, on 5 November 1914, under the leadership of Clark and Harvey. The group included two doctors and a medical student, two pharmacists, a dozen or so trained nurses (including midwives and district nurses), an experienced female relief worker, and a sanitary inspector, as well as other men disposed to work as drivers, orderlies, and general labourers. In Paris, however, the eager volunteers were met with an avalanche of frustrating bureaucracy that caused an unexpected halt to their plans. While Clark and Harvey were locked in a seemingly endless process of consultation, discussion, and permit seeking, the rest of the group familiarised themselves with their surroundings and practised their French. Dr Marjorie Franklin noted that they also took the opportunity to visit several medical facilities:

I don't think I could convey to anyone who had not experienced it the extraordinary network of permits and prohibitions in which we are involved under a state of martial law. For instance, when everything was nearly settled for one place, an order from General Joffre allotted the party to work under a different army-however, we managed to do both in the end. This delay enabled us to visit a good many hospitals in Paris. We were received at them warmly and shown a lot. 22

Finally, the Friends obtained the necessary permits to proceed. Clark, not one to mince her words, wrote to her family that the over-lengthy discussions had been in no small part due to Harvey's 'excessive politeness' ${ }^{23}$ Clark was even less impressed by the attitude of General Azibert, commanding DES of the 5th Army, who assigned the Quaker Mission (as the French called the FWVRC enterprise) to the area of the Marne. Clark complained to her sister Alice that the general was of the opinion that the war zone was no place for women.

19 Pye and Clark met in London in 1908. Pye joined the Society of Friends soon afterwards, and the two became inseparable, lifelong friends.

20 Though the Friends would attempt to maintain total independence from the military, in practice, this was not only impractical but impossible for any organisation functioning within the war zone.

21 Anonymous, in a supplement to The Friend, 6 November 1914.

22 Dr Marjorie Franklin, "Medical Diary of World War One: 31 December 1914. http://www.pettrust.org.uk/ pettasc/index.php?option=com content\&view=article\&id=559:medical-diary-of-world-war-one-november-22nd-1914\&catid=60:archive-1\&Itemid=176 (accessed on 13 September 2020).

23 Hilda Clark, letter to Alice Clark, 19 November 1914, Friends' House Library (FHL), Hilda Clark Papers: TEMP MSS 301 (from hereon, HCP). 
'Of course,' she concluded, 'I shall fight that tooth and nail ... I shall take jolly good care that I get everywhere the men $\mathrm{do}^{\prime} .^{24}$ It is clear that Clark's identity as a woman played an important role in her humanitarian activities with the FWVRC during and after the First World War. Her activism openly broke with the established gender model, helping to debunk the mythical representation of women in the history of humanitarian relief as 'loving angels or compassionate mothers' ${ }^{25}$

\section{Relief Work Gets Underway}

Providing aid in the war zone was a complex and difficult undertaking involving much more than the mere distribution of food and clothing, as there were thousands of refugees needing help of many different kinds. Some villages remained almost intact, while others had been completely razed to the ground. There had also been much pillaging and destruction, and in addition to the damage to homes, there was also the loss of agricultural tools, small stock and crops, and various other kinds of property. The small government grant given to refugees barely covered the cost of food, let alone warm clothing or blankets and farming implements; therefore, with characteristic pragmatism, kindness, and patience, the Friends set about learning how best to help. The ultimate aim of the FWVRC was that at the heart of all such Quaker ventures: to help people to learn how to help themselves and how to rebuild their shattered lives. Ruth Fry explained:

The hungry were fed, the naked were clothed, the sick were visited, the prisoners were ministered unto, not for any elaborate reason, but just because they were utterly miserable and needed help. ${ }^{26}$

General relief, building, and agricultural work was carried out by a sixteen-man team under the direction of Harvey, with the devastated town of Sermaize as its headquarters. Before the advent of war, Sermaize had been a prospering little town of about 4000 inhabitants, renowned for its medicinal springs and sugar manufacturing. When the FWVRC arrived, the remaining population was living in insanitary conditions, mainly below ground, in the cellars of what had once been their homes.

In collaboration with the local authorities, the FWVRC carried out extensive enquiries into the need for relief in some twenty surrounding villages. In addition to supplying emergency relief in the form of food, clothing, and footwear, work was begun on the repair and reconstruction of homes and farm buildings and on the improvement of sanitation. With farm machinery destroyed, horses requisitioned for military use, and all the younger and able-bodied men occupied on the fighting fronts, many families were unable to farm their land. The FWVRC provided agricultural tools and machinery and even provided labour, where necessary. Some of the larger equipment, such as mowing and threshing machines, was provided on loan and made available to the entire community. FWVRC volunteers also went out into the countryside with seeds for planting and small stock such as sheep, goats, poultry, and rabbits, which skilled refugees then bred and reared. The Friends set up cooperative shops where food, household goods, furniture, tools, and seeds could be bought at cost. Further initiatives included the creation of sewing workshops for women and girls and market gardens for the men and boys, as well as providing schooling for children. The efficiency and compassion with which the FWVRC fulfilled its allotted duties impressed the French authorities, and it was allowed to expand its field of operation.

\section{Medical Work Begins: La Maternité Anglaise, Châlons-Sur-Marne}

Clark led the medical team, with the town of Châlons as the centre of its operations. Fortunately, upon the FWVRC's arrival in France, there was little evidence of the feared

24 Hilda Clark, letter to Alice Clark, 19 November 1914 (HCP).

25 Martín-Moruño (2017), “Tejiendo redes de cuidado. La compasión como conocimiento de las mujeres humanitarias en la guerra (1853-1945)”, in Alfons Zarzoso and Jon Arrizabalaga (eds.), Al servicio de la salud humana. La historia de la medicina ante los retos del siglo XXI, (Ciudad Real: QL Printers, 2017, 21).

26 (Fry 1927, p. viii). 
outbreaks of disease, and apart from numerous cases of scarlet fever and measles, the general health of the people seemed good. 'Good climate and sturdy people!' noted Clark. ${ }^{27}$ Nevertheless, as the majority of civilian doctors had been mobilised and civilian hospitals had been requisitioned for military medical needs, the Friends would soon be providing valuable and most welcome medical assistance throughout the region. Clark created a number of vital medical facilities, including hospitals and convalescent homes. Country practices were also established, and extensive district nursing carried out in the more remote villages. However, the FWVRC's first and most enduring medical venture was the maternity hospital at Châlons-sur-Marne. The hospital opened its doors on 14 December 1914 and was eventually handed over to the French as a permanent memorial of the Mission of the Society of Friends in September 1919. By then, it had become a symbol of true international collaboration 'thoroughly imbued with the spirit and ideals of the Mission'.28

Châlons sur Marne (now Châlons en Champagne) is about $110 \mathrm{~km}$ directly east of Paris and $50 \mathrm{~km}$ southeast of the city of Rheims, which was, when the FWVRC arrived, under heavy bombardment by the Germans. The town had earlier been occupied by the Germans for only nine days and had suffered very little as a consequence, but it lay in the centre of the Marne district into which had teemed thousands of refugees from the surrounding area and from further north, from the Meuse and Ardennes. About fifteen miles from the front, it meant that the town was also overflowing with military personnel, and life (such as it was) went on there to the constant booming of guns.

The pleasant town of Châlons was situated in an agricultural region, flanking the river Marne. American aide, Esther Whitson, described 'deep green moss-bordered canals moving under quaint bridges, donkey carts led over cobble-stone pavements by women with little children and mud, mud, mud, and water' ${ }^{29}$ The town boasted several emblematic buildings including the Saint Etienne Cathedral, the Hôtel de Ville, the beautiful Notre Dame church, and the Hôtel Dieu (the hospital). Hidden from view behind the quaint main streets, however, were assorted slums, condemned before the war as unfit for human habitation; they were now teeming with those refugees who could manage to pay the exorbitant rents being demanded by unscrupulous landlords. Others found shelter in the enormous barracks on the outskirts of the town or in the vast champagne cellars tunnelled into the hillside, while the remainder made what use they could of lofts, sheds, and barns, sometimes alongside their animal occupants. Marjorie Franklin wrote:

Chalons is too busy and too full to take any notice of these people and they are living in great distress, some of them literally in barns and stables with hardly any light or fire (most have fire, but some are even without that) and sleeping on straw, occasionally with only sacking to cover them. Most of them have their military allocation ( $1.25 \mathrm{fr}$ for wife and $50 \mathrm{c}$ for each child) for a part of the household, but there are usually relatives living them with who haven't it and any way it is not enough to re-clothe themselves. The people are mostly wonderfully cheerful and courageous. ${ }^{30}$

The refugees were, for the most part, destitute; thus, the immediate relief brought by the Friends, in the form of clothes and blankets, was of vital comfort, especially in view of the approaching winter. 'Oh, how thankful I am that we were here in time to do something before the cold', Clark reports home. ${ }^{31}$

Dr Hilda Clark, Dr Dyson Holdsworth, and the party of FWVRC nurses were given a particularly warm welcome when they arrived in Châlons in November 1914. The town's

27 Hilda Clark, 'Society of Friends' War Victims Relief Committee Medical Report for non-combatants in the departments of the Marne and the Meuse, during the months December 1914-April 1915', HCP.

28 Edith Pye, Suggestions for the continuance of the Chalons Maternity (undated). (FHL, FEWVR).

29 Esther M. Whitson, excerpt of a letter published in the Quaker journal, The Friend, 30 March 1922.

30 Franklin, 'Medical Diary of World War One'.

31 Hilda Clark, letter to Edith Pye dated December 1914, in Edith (Pye 1956, p. 23). 
civilian hospitals were the Hospice Saint Maur and the Hôtel Dieu, the latter being the only medical establishment in the town with maternity facilities. With the influx of thousands of women and children from the surrounding occupied and bombed districts, it became impossible to provide professional maternity and post-natal care. The prefect (préfet) of the department, Monsieur Chaprón, was in desperate need of help in finding accommodation and care for some 200 maternity cases. Many were living in dreadful conditions, and they could not easily be reached by French philanthropic agencies.

Monsieur Chaprón suggested that the Friends open a maternity hospital, offering for the purpose a wing of the town's Asile des Vieillards, the home of 'the aged, the imbecile and the epileptics'. The asylum was created by the General Council of the Marne in 1885 to house the old and infirm, the mentally ill, and epileptics. In addition, there were beggars sent by the courts and those who presented themselves voluntarily. It is not entirely clear just how much the prefect's suggestion was influenced by the fact that the volunteers could work there without interfering with military operations. While staff would be provided by the Friends, the necessary alterations to the building would be carried out by the French authorities, who would also be responsible for the provision of fuel and maintenance costs. ${ }^{32}$ The Comité $d u$ Secours National, for example, pledged GBP 120 per month. There had been no plans for the Friends to undertake maternity work in France, but the need was acute-most midwives had fled, and almost all eligible doctors had been mobilised.

The imposing Asile des Viellards lay on the northern edge of the town in what, from a military point of view, was considered an exposed position, but it was also on good communication lines, with easy access to both road and rail. ${ }^{33}$ The wing allotted to the Friends, the pavillon des oiseaux, was on the north side of the institution, looking out over pleasant open countryside and interrupted only by the tree-lined Route de Suippes, leading up to the front. The building had a rather foreboding appearance, accentuated by its stone floors and enormous, barred windows. Pye reported:

Built in separate blocks, of an ugliness almost unbelievable, like match-boxes set up on edge, within, the wards were light and lofty, ventilation good and adaptation seemed possible. The one offered to us had been the epileptic block, and so the ten-feet windows were caged in with wire netting, but they opened inward, and only to the discontented occasionally suggested a prison. ${ }^{34}$

The staff had been depleted by the needs of war, and the state of the wards was well below acceptable standards of the day. While Pye described the toilet facilities as 'sanitary conveniences of a hair-raising type', ${ }^{35}$ Clark reported, with characteristic candour, that conditions were such as one would rarely find in the 'oldest and dirtiest English Workhouses'. ${ }^{36}$ The asile had a poor water supply, insufficient lighting in the form of oil lamps, and totally inadequate heating. Furthermore, its lack of cellars meant that it could offer no shelter in the event of a bombing raid, making it a less than ideal choice as a hospital. However, choice played little part in the matter: these were difficult times, and no more appropriate premises were available.

After most of the epileptic women had been housed elsewhere, the FWVRC volunteers set about preparing the hospital. The whole team, including doctors and nurses, scrubbed and scoured and swilled from dawn until dusk for two solid weeks, observed by the

32 The préfet of the Marne requested the director of the local Asile de Vieillards y dépôt de mendicité to provide space in the institution to house a temporary maternity hospital. The Archives Departamentales de la Marne hold this letter and other correspondence between the prefect, the director of the aisle, and the staff of the hospital (chiefly, Edith Pye). Reference: ADM CEC H dépôt 1321 Maternité 'anglaise' departamentale (from hereon, ADM). The director, Monsieur Becq, notified the préfet of his willingness to oblige and suggested, as most appropriate, the 'Pavillon des oiseaux', the wing for 'femmes gâteuses, idiotes et épileptiques'. He also requested alternative accommodation for those presently occupying this wing. (ADM CEC H dépôt 1321 Maternité 'anglaise' departamentale. Installation, organisation, divers registrés d'entrées (1914-1922)). Letter from the préfet of the Marne to the director of the Asile des vieillards y dépôt de mendicité, 14 November 1914.

33 This meant that supplies could be delivered when the rail transport was available and not requisitioned by the military.

34 (Pye 1956, pp. 18-19).

35 (Pye 1956, p. 19).

36 Edith Pye, 'Report on the work undertaken by the War Victims Relief Committee of the Society of Friends at Châlons-sur-Marne for the three months, December 1914-February 1915 inclusive'. FHL, YM/MfS/FEWVRC/MISSIONS (from hereon, FHL, FEWVR). 
assortment of bemused inmates who remained in the building. Dr Marjorie Franklin noted that she was sent to Châlons to help Clark's team with the asile:

The hospital was started on the initiative and at the request of the Prefet of the Marne, and the department paid for all the alterations and pays for the upkeep, furnishing etc, for the funding of the équipe and lodging of the hospital staff as well as free petrol for the motors [ ... ] we were joined almost at once by other nurses and at first we all had to set to and sort and clean our beds etc- the place was filthy beyond description-and our first "medical" work was to kill the undernourished inhabitants of the bedsteads and lockers etc! while our chief surgeon scrubbed down wards, with the assistance of 1 or 2 men from another contingent of our party. ${ }^{37}$

Midwife Edith Pye had not volunteered to go to France with the first party, as she was unsure that she would be strong enough for the work involved. However, she went at the beginning of December, after Clark implored her to help with running the maternity hospital. She soon wrote home to the Committee that she was 'tough as old boots' compared to some of the volunteers sent out to help her. ${ }^{38}$ While Clark was responsible for setting up the maternity hospital, it was Pye who would run it. She administered the hospital, as well as fulfilling her role as midwife and training volunteers. It was she, and not Clark, who would later be decorated for her work by the French.

The prefect commissioned local architect Monsieur Dupont to carry out the necessary alterations, and after painting and the final disinfection, the maternity hospital was finally ready. 'It was a trying ordeal,' declared Pye, 'but it ended at last and the building, bare but clean, was ready for the new life that soon urged into it'. ${ }^{39}$ The dining room, on the ground floor, would become the nerve centre of the hospital. This was where all the administrative business was conducted and where the staff congregated when off duty. When the weather was bad, it also provided a playroom for the children being cared for there. There were also six cubicles for the nurses, with other staff occupying two small rooms in the loft. As the ground floor was paved with stone, the maternity wards were installed on the first floor. There was a small labour ward and a ward of twelve beds with twelve cots for mothers and babies, as well as a waiting ward and a convalescent ward. There was also a small isolation ward and a dispensary for the storage of drugs and instruments and other useful commodities (such as condensed milk and Bovril, noted Pye). ${ }^{40}$

In the centre of these rooms was the ward kitchen, and at the end of each ward, there were toilets. Hot water had to be heated on stoves or in a large boiler, and lighting was provided by paraffin lamps and a few petrol-burning lamps, which, noted Pye, were less effective than candles. She added: 'When in 1917 the American Red Cross paid for an installation of electric light, we thought we were in paradise' ${ }^{41}$ In the centre of the aisle was the chapel, where catholic services were held and those mothers who wished it had their babies baptised. ${ }^{42}$

The domestic staff was provided by the director of the asile, Monsieur Becq, from among the least incapable of his mentally ill female patients. They were, on the whole, very eager to please but provided the Friends with some often rather startling 'entertainment'. Pye furnished tales of women dirtying the wards instead of cleaning them, another unwittingly setting light to herself, and one hopeless alcoholic who begged the nurses to hide her boots so that she might be prevented from straying to the nearest fount of her

Dr Marjorie Franklin, 'Medical Diary of World War One: November.

8 (Pye 1956, p. 19).

9 (Pye 1956, p. 19).

40 Edith Pye, 'Society of Friends war Victims' Relief Committee: Relief work in the Devastated Department of the Marne, November 1914 to February $1915^{\prime}$ p. 3. (FHL, FEWVR).

41 (Pye 1956, p. 19).

42 The hospital records contain several letters from individuals requesting written certification of their baby's baptism during their stay at the maternity hospital. See, for example, ADM CEC H dépôt 1321, 29 May 1921. 
ruin, so anxious was she to be allowed to remain in the hospital. Clark wrote home: 'The third ward maid is a dipsomaniac [ ... ] and more dangerous, really, than any zeppelin. ${ }^{\prime 43}$

The first ward at the Maternité Departmentale (or 'Maternité Anglaise', as it became known) was opened on 6 December 1914, and its first baby arrived just three days later. Marie Louise, referred to affectionately as 'la petite Anglaise', was the ninth child of a refugee mother from Ardennes. Like so many others, the mother and her family had lost everything. They had fled their bombed and burning home with only the clothes they were wearing and were now living in appalling conditions. With no safe place to leave them, the mother had brought six of the children with her. This case alerted the staff to the need for the provision of care for the older children of mothers admitted to the hospital, and a crèche and two dormitories were provided for them on the ground floor.

Women seeking admission to the hospital for maternity or post-natal care had to make a written request to the prefect. If the petition was accepted, she received a 'billet d'entrée à $1^{\prime}$ Asile Départementale'. ${ }^{44}$ The prefect kept a watchful eye on the functioning of the hospital and the comings and goings of both patients and staff. He had to be informed of the date and time of every entry, release, or transfer of patients. In the case of transfers, it was his responsibility to inform those in charge at the new institution of their imminent arrival. ${ }^{45}$ As hospital administrator, Pye was obliged to inform the prefect of the arrival and departure of maternity staff-information that he passed on to the local police. ${ }^{46}$ As he was the departmental representative of state, he also kept the appropriate ministers informed.

The director of the asile requested that the prefect address the General Council to fix a daily rate (prix journalier) for patients and their children in the hospital. The daily rate for hospital patients, fixed by law, was FF 2.50 per adult and FF 0.50 per child, but the massive influx of refugees in wartime meant that this would have to be reduced, and State help requested. ${ }^{47}$ The asile would be responsible for the maintenance of the medical personnel and the wages of the domestic staff, as well as the costs of heating and lighting, medical supplies, and most of the food and milk for the babies cared for. ${ }^{48}$

Patients were provided with the healthiest of diets obtainable in wartime conditions, and records show purchases of supplies including bread, mutton, beef, chicken, fish, eggs, and fresh vegetables. ${ }^{49}$ Each patient was allotted 1 litre of milk per day, including that served in coffee at breakfast. Milk was particularly difficult to obtain in conditions of war, however, and costs were often excessive. Consequently, on some occasions, Monsieur Becq requested Monsieur Chaprón's permission to provide the maternity wing with supplies from the asile's existing stocks. In the winter of 1917, for example, 1000 cartons of concentrated milk, as well as $100 \mathrm{~kg}$ of tapioca and powdered chocolate, were contributed. ${ }^{50}$ The hospital also received donations of milk, chocolate, and other foodstuffs from various other sources. ${ }^{51}$ Records show that meals were adapted to the particular condition of the patient (that is, pre- and post-natal). For example, women approaching labour were not given meals containing either cabbage or sorrel, both proven to reduce the production of breastmilk.

Soon, the hospital was functioning to capacity. ${ }^{52}$ Clark expressed a certain satisfaction with what had been achieved:

43 Hilda Clark, letter to Esther, 10 March 1916, HCP.

44 ADM, L'Union républicaine de la Marne. 25 Novembre 1914: 'Pour les femmes émigrées'.

45 ADM dépôt 789, Guerre de 1914-1919: refugiés et evacuation de l'hospice en 1914-1919. Letter from the prefect to the director of the asile, 19 April 1917.

46 ADM 1321 Letter from the director of the asile to the Police Commissar, 17 May 1915.

47 ADM, 28 November 1914.

48 ADM, 23 March 1919

9 ADM, 18 March 1915.

ADM CEC H dépôt 1321, Letter from director of asile to préfet, 25 October 1917.

51 The French commune of Sainte Foy l'Argentière donated chocolate. ADM, letter of director of asile to préfet 25 October 1917.

52 FWVRC, 'Work undertaken by the war victims' relief committee of the Society of Friends at Châlons-sur-Marne for the three months December 1914-February 1915, inclusive'. (FHL, FEW). 
I am reposing in great bliss as the worst anxiety of failures and muddles are over and we have succeeded both in being of enough use ourselves to justify coming out, and all the expenditure, and in opening up the way to help the awful suffering which we knew all along was here. We have got the confidence of both civil and military authorities and if in the next few weeks we can make this good, I think the limits to our work will be those of the capacities of ourselves and the volunteers who are waiting. ${ }^{53}$

Clark confessed that, after she had 'longed to run away' during the first month, the Friends had been proven totally justified in going out to France. She added: 'I feel that by sheer work we shall keep things going, whatever happens' ${ }^{54}$

A second ward was ready to receive patients on 1 January, and after a couple of weeks, there were continually more patients than beds. In February, 56 cases were treated. There were 25 births, giving a three-month total of 63 babies born ( 28 males and 35 females). ${ }^{55}$ Mothers spent an average of 24 days in the hospital, and before being discharged, they were given clothes for themselves, the baby, and their older children. They were then visited afterwards, in their homes, to monitor progress. The field notes of Dr Marjorie Franklin give some indication of the predicament of the women concerned:

Mme Dehan, a young woman, emigrée from Lenharrée, living with with her parents, Mons and Mme Danneyeux. Her house and farm were burnt and her husband was killed at the front. She is not intending to return to Lenharrée. Family-boy $3 \frac{1}{2}$, girl 2.

Mme Dehan is expecting to be confined in the spring. She prefers to remain at home.

She has lost everything and only has army allocation (f1.25 for self and 50c per child, per diem), which has been continued since husband's death, but she is looked after and housed by her parents.

Mme Petit (whose husband is a soldier) and 6 children-a boy of 5 , girl 4, a boy of 3 , twin girls of 2, girl 1. The mother expects to be confined in April and would like to enter our Chalons hospital. Their house and possessions were burnt and they seem very poor and have not received the allocation due since the husband was mobilised, in spite of the maire's endeavours [... ] At present they are all living with the parents-in-law, and are rather crowded. A poor family, the children in need of clothes and in weak health. ${ }^{56}$

The maternity hospital was created especially for sinistrées-women whose homes had been destroyed-in the Marne and elsewhere, while the townspeople of Châlons were cared for in the Civil Hospital where there was a small maternity department staffed by a religious order. There were excellent relations between the two hospitals. Dr Evrain, the senior surgeon at the Civil Hospital, was also the medical attendant of the departmental asiles, in addition to fulfilling military duties, and he very much welcomed the Friends' help, as did other French doctors. Often, these were quite senior men who had come out of retirement, under the exceptional circumstances, to offer their services and they usually welcomed any help they could get.

The Friends' work was also greatly appreciated by the local authorities. The prefect was a frequent visitor to the hospital. He thought that the maternity services available to serve the needs in the country districts were inadequate even in times of peace, and he expressed the desire that this new facility created by the FWVRC become a permanent institution. The local population of Châlons also showed interest in the work of the Friends.

Letter to unknown relative, December 1914, in (Pye 1956, p. 23).

4 Letter to 'Dearest snail', December 1914, HCP.

55 While the Friends' records are limited to stating the number of boys and girls among the births registered, French records also identify those babies who were 'illegitimate'.

56 These are just two examples of very many cases noted by Franklin, 'Medical Diary of World War One'. 
Some visited the confined women and took them gifts of clothing for their newborn babies. The Friends received many letters of thanks from patients and their relatives expressing their enormous gratitude for the kind and expert care they had been given. Below is an extract of a letter from a husband at the front. It is typical of many:

I beg that you will receive my thanks for all the care you have lavished on my wife. I should have fallen short of my duty had I neglected to testify my gratitude to you personally, and to all the devoted persons who surround you. I hope also that my wife, whom you have saved from death and also my little child, so beautifully cared for, will carry away an unforgettable memory of the Society of Friends. ${ }^{57}$

The following is a letter from the patients to the staff of the hospital on New Years' Day, 1915:

On this, the morning of the 1st of January, we feel it a duty to come to offer you our best wishes for the year now beginning. We want to tell you how much we are touched by the cordial welcome we have received under your roof and by the good care with which you have surrounded us, and which helps us to forget the hard times which this war has laid on us.

Without your charitable work, what would have become of us? We realise it, and our gratitude towards you equals our thanks. We will tell our children what you have done for them and for their mothers, as well as of all the good works with which your path is sown. (Signed) The group of young mothers. ${ }^{58}$

In April 1916, a pouponnière, for sick children, was created in the hospital. On the day it opened, five sick children were admitted, but monthly admissions quickly increased. The following month, there were 17 children being cared for on 23 July and on 28 August. ${ }^{59}$ Once the maternity hospital was up and running properly, Clark began to put into action further plans, as Pye explained:

The work of the Châlons Maternité, though it was of immense importance to the French officials with whom we had to deal, was only a small cog in an immense wheel of which Hilda Clark was the hub. It is also true that it proved to be the enduring memorial of the Friends' work in the Marne, but it was only one of the growing points of Hilda Clark's concern. She had a clear vision of what Friends and those who thought as they did could offer to a country at war. Her vision and organising power outreached the ideas of other workers - she saw what needed to be done and held people to it. Not only did our own workers accept her ideas, but she was able to convince and carry with her French officials at every level. Perhaps it was her simplicity and her conviction that awoke an echo in those she sought to convince-certain it is that she was seldom refused. ${ }^{60}$

The medical work in Châlons was inextricably linked to general relief work in the town. As the fighting went on, refugees continued to stream in from Reims and from the smaller towns of the Marne, but many were unable or unwilling to go further than Châlons and the neighbouring villages. The mayor of Châlons withdrew the government allowance for a while to encourage them to move on further south and was reluctant to cooperate with the FWVRC in facilitating the distribution of aid among the neediest. ${ }^{61}$ In this respect, the assistance of local couple Commandant and Madame Thévenard proved invaluable.

57 Hilda Clark, 'Report on the work undertaken by the War Victims' Relief Committee of the Society of Friends at Châlons-Sur-Marne. For the three months, December 1914-February 1915, inclusive', p. 7. (FHL, FEWVR).

58 Hilda Clark, 'Report on the work undertaken by the War Victims' Relief Committee of the Society of Friends at Châlons-Sur-Marne. For the three months, December 1914-February 1915, inclusive', p. 7. (FHL, FEWVR).

59 ADM report: États des personnes présentes à la Matermité.

60 (Pye 1956, p. 16).

61 Hilda Clark, 'Report on the work undertaken by the War Victims' Relief Committee of the Society of Friends at Châlons-Sur-Marne. For the three months, December 1914-February 1915, inclusive', p. 8. (FHL, FEWVR). 
Reserving just two rooms for their own use, they gave the Friends lodgings in their home and put the stables, barn, and outhouses at their disposal. ${ }^{62}$ Their home at 16 Rue Titon was (and still remains today) in a narrow, cobbled street in the centre of Châlons, just a short stroll from the main square. The coach house was used as a garage for the cars belonging to the maternité, with the chauffeurs also lodging with the Thévenards. The rest of the outbuildings housed the FWVRC Relief Centre, which became an important part of the Friends' work in the town, as did Madame Thévenard herself. She visited schools to inform the mothers of needy refugee children that they could apply to the Friends for help. She then took the names and addresses of those wishing to apply and explained the procedure. Her knowledge of the town and the department proved invaluable to the Friends who were able to ascertain the needs of individual families and provide suitable clothing. The collaboration of prominent local figures, such as the Thévenards and the prefect, was crucial in gaining the confidence of the people most in need of the Friends' assistance.

\subsection{Sermaize Hospital}

In June 1915, Clark created La Source Hospital, Sermaize, close to the Sermaize-lesBains establishment being used as the FWVRC's headquarters for the war zone. The small hospital began with a wooden hut containing two rooms, with accommodation for two or three patients in each, one having a balcony on which two beds could be placed. There was a kitchen/living room for the nursing staff, a small bedroom for one nurse, and a store room and dispensary. There was also an equally small sanitary block. The hospital was intended for emergency cases amongst the many refugees in the neighbourhood, but it expanded to care for children from Reims who were too ill to benefit merely from being in the country. A second block was therefore added to the hospital, containing a ward with eight beds, a room for the nurse, a small day room, and a large balcony on which several beds could be placed.

\subsection{Bettancourt Convalescent Home}

Shortly after the creation of the Sermaize hospital, in July 1915, a convalescent home for children was created in a chateau at Bettancourt-la-Longue, about three miles from Sermaize. It was loaned to the Friends by its owner, the Comtesse Morillot. British couple Mr and Mrs E. V. Lucas equipped and managed the institution for a year, with the generous financial backing of their friend, author J. M. Barrie. It was occupied by an average of 40 to 50 children. When a doctor was placed there permanently, it could offer hospital care, as well as a well-attended outpatient clinic. During the first year, 225 children were admitted. Additionally, 20 women were admitted, mainly pre-tubercular cases.

\subsection{Hotel Belle Vue, Samoëns}

By the spring of 1916, there was mounting concern for those in the convoys of rapatriespeople being sent back into France from German-occupied territory. These were people deemed by German doctors to be unfit for work and therefore of no use. An estimated one hundred thousand had arrived via Annemasse, near Geneva, about $50 \mathrm{~km}$ from Samoëns. Many were in poor physical condition, and the FWVRC decided to open a centre, near the place of their arrival, for those needing medical care. The Hotel Belle Vue fit the purpose.

Belle Vue was set in Alpine gardens at an altitude of about $700 \mathrm{~m}$, not far from Mont Blanc. The hotel comprised two large chalets that could accommodate 100 people. Later, when the Germans ceased to allow refugees to return to France, the home was used for women and children refugees in Paris (and other overcrowded centres) whose health was suffering as a result of prolonged hardship, malnutrition, and unhealthy living conditions.

62 Memoir of relief worker Sara Renton. (Author's personal archive). 


\subsection{Country Practices and District Nursing}

In Fère Champenoise, the FWVRC established a small medical practice serving twentyfour villages, with the doctor and nurse making home visits covering a radius of about $15 \mathrm{~km}$. In Bar-le-Duc, the French doctor welcomed the FWVRC's assistance at the municipal dispensary. This was normally run by women of the French Red Cross, but they had been called to military hospitals. In addition to running the general clinic, the FWVRC nurses held an infant clinic there one day a week.

District nursing was carried out, in several villages, by FWVRC nurses under the direction of French doctors. It was challenging work, especially in winter when the nurses spent long hours 'tramping or bicycling in impossible mud' to tend to their patients. ${ }^{63}$ As well as giving care and advice, they distributed sheets and blankets, medicines, and other essential aid among their needy patients. This service, a scarce luxury in France at that time, was greatly appreciated. The ailments treated included febrile conditions such as influenza, bronchopneumonia, pleurisy, rheumatic fever, and tonsillitis, as well as some tubercular cases. Children formed a large percentage of patients, especially up to mid-March 1915, when scarlet fever and measles were present. There were also some patients with shell wounds. Chronic cases, such as those with bronchitis, asthma, and heart problems, were tended to when time permitted. Optical and dental care was also given. ${ }^{64}$

Clark personally oversaw the creation and maintenance of each branch of the work and drove constantly between the different centres and the Paris headquarters, where she also directed medical assistance among some of the many thousands of refugees. An expert in the treatment of tuberculosis, Clark was particularly concerned about the pre-tubercular cases she had detected among those people crammed into the capital's overcrowded slums, some of whom would be sent to Samoëns.

From May 1915 to April 1917, the FWVRC was also involved in the enormous task of evacuating hundreds of children from Reims under heavy shelling from the Germans. ${ }^{65}$ The children were first taken to the Châlons maternity hospital, where they were given a medical examination and fed and clothed before being sent on-some to French families and others to the FWVRC convalescent homes at Sermaize and Bettancourt.

\subsection{Problems with Volunteers and the London Committee}

With the expansion of the work, more volunteers were needed, but it was far from straightforward to recruit them and get them out to France. In order to be allowed into a war zone, each volunteer needed a permit from the French Red Cross and a Carnet $d^{\prime}$ Etranger, in addition to a passport. Such permits could only be issued by the already overstrained military authorities, which inevitably caused long delays. In addition to the endless red tape involved, it was not an easy task to find candidates for work in France who satisfied the wide range of requisites stipulated by Clark and Pye. In general, candidates were required to be competent and amiable, physically fit, and capable of living in basic conditions. Clark expanded upon these requirements:

We want someone with a good deal of nursing and sanitary experience if possible, with fluent French and a bicycle. Really, someone with a grip of things and an interest in illness and children and smells and an idea of teaching and sympathy and can do the work quite well without regular hospital training, provided she understands what she ought to get help for and does not think she knows everything! ${ }^{66}$

Perhaps unsurprisingly, several of the volunteers that Clark was sent fell short with respect to one or more of these exacting credentials, and matters led to strained relations

(Fry 1927, p. 52)

64 Dr Joseph Woods, a dentist from Liverpool representing the Committee, lived in Switzerland for a considerable time in order to give free dental help to English prisoners of war who were interned there.

65 There were, at that point, less than 30,000 people left in the town out of a population of around 120,000.

66 Hilda Clark, letter to Alice Clark, 17 June 1915, HCP. 
between Clark and Fry, in charge of the London headquarters. ${ }^{67}$ Nevertheless, the Châlons Maternity Hospital continued to flourish. By August 1916, the total number of cases nursed was 1399 (including 409 evacuees from Reims). A total of 300 mothers had been cared for, and 294 babies born (159 girls and 146 boys). Surgical cases numbered 29, and medical cases 54. A total of 227 children had been cared for in the hospital crèche, while there were 575 home visits and 72 vaccinations given. This work was considered crucial, as it enabled the early detection of illness and, thus, the aversion of potential epidemics. ${ }^{68}$

All through 1917 there were very great difficulties with papers and permits, and no extra workers could be obtained from England. It was the hardest winter on record for those parts, and Pye reports that it was almost impossible to obtain fuel, food, and milk. She concluded: 'in fact, almost the only commodity that did not fail was babies. ${ }^{69}$

\section{America Joins the War}

In March 1917, the staff of the maternité, overworked and desperately understaffed, were grateful for the arrival of American volunteers from the American Friends Service Committee (AFSC). ${ }^{70}$ After this point, it is difficult to ascertain where British aid ends and American aid begins. The two forces merged, British and American volunteers worked alongside each other in several of the relief schemes in place. They took joint responsibility, for example, for the reconstruction of an area of about $200 \mathrm{sq} \mathrm{mi}$ in Lorraine, near Verdun, where only five percent of the houses remained standing. ${ }^{71}$ Medical work was considerably expanded, with one identifiably American undertaking being the new Chateau Hospital at Sermaize, under the leadership of Dr James Babbit.

Dr Morris Slemons, Professor of Obstetrics at Yale University, declared the work done by the maternité at Châlons to be 'excellent'. He concluded his report as follows:

The quality of the work already done by this institution, the resulting confidence in which it is held by the civil authorities and the devotion of all the patients who have been treated there together indicate that the institution will become a permanent one. It will also serve as a model for similar institutions which will probably be needed in other localities. ${ }^{72}$

American collaboration, in terms of financial, moral, and material help, proved vital to the continued work of the FWVRC. As usual, Clark made clear her views. She thought it was a good idea to welcome American Friends-but not many of them. 'Those who have already joined us seem nice people,' she wrote, 'but not at all decided in their views, and I don't know how many of those waiting in America will really wish to join us when they realise that we expect the men who join us to agree with us. ${ }^{73}$ In fact, after initial teething problems, the American and British workers united wholeheartedly in providing extensive relief for the civilian victims of the war and extending the medical facilities available.

Thanks to American funding, medical work was greatly extended in the districts of Marne and Meuse. This included a new surgical hospital at Sermaize under the leadership of American ear, nose, and throat specialist, Dr James A. Babbitt and the 'baby house' at 17-19 Route de Suippes. The annex for babies opened on 18 January 1918. Separating some mothers from their children was not an ideal arrangement, but it freed up much-needed space in the maternity hospital. The house stood in its own grounds, complete with a

67 Storr suggests that another reason for the tense relationship between Clark and Fry may have been partly related to suffrage. Edith Pye and Hilda Clark were both members of the militant Women's Social and Political Union, of which Fry may have disapproved. (Storr 2010, p. 156).

68 FWVRC, 'Report on the medical work undertaken by the F. W. V. R. Expedition in France', November 1914-September 1917. (FHL, FEWVR).

69 With the budget for the hospital, Edith Pye organised the purchase of two cows with the idea of supplying milk. Sadly, the cows in question were too malnourished to produce milk and were sold at a loss. Another cow in full milk was bought, and an arrangement was made with a local farmer to house and milk it and supply the hospital.

70 The AFSC had been created on 30 April 1917, just 22 days after the United States entered the war.

71 Financial aid from American Quakers had, of course, preceded them. By May 1915, there were an estimated 49 American-financed relief initiatives in France and some 730 in the USA. See Yves-Henri Nouailhat, La France et États-Unis, août 1914-avril 1917. Paris: Publications de la Sorbonne, 1979.

72 J. Morris Slemons, 'The Maternity Hospital at Chalons, conducted by the Society of Friends', 28 September 1917, p. 2.

73 Hilda Clark, letter to Mother dated 24 July 1917, HCP. 
garden, large vegetable plot, small orchard, and several outbuildings. The house itself had 15 rooms, including a large kitchen and bathroom and a water supply up to the first floor. There was also a terraced roof with a shelter that could be used as an open-air ward. A total of 13 babies from 9 months to 2 years were packed into Emily, the new motor car, for the jubilant run to the new premises. More were transferred a few days later. In the new and spacious environment, where they had ample room to play, the infants' health rapidly improved. ${ }^{74}$

By May 1918, intensified bombing raids had caused large numbers of emigrés to leave Châlons. The maternité anglaise, however, continued to be very busy and even more so after receiving the evacuated patients of the Hôtel Dieu. A total of 29 babies were born. ${ }^{75}$ In June, the maternity hospital at Epernay was also evacuated directly to the Châlons maternité, now making this the only one still functioning in the department. A total of 15 new mothers (either with their babies or waiting) were admitted in two days, and there was a total of 25 births. The highest number of patients under the roof of the maternité in any one night was 99 , with the total number of births standing at $737 .{ }^{76}$ In July 1918, Clark finally succumbed to the strain, and exhaustion and ill health obliged her to return home to rest. Once recovered, she would use her experience in France and her constant religious faith to plan the next stage of her international relief work in the name of the Friends. ${ }^{77}$.

\section{The Châlons Maternity Hospital Is Evacuated}

On the morning of Friday 12 July, after a terrifying series of air raids on Châlons, the French military finally announced that immediate evacuation of the asile was necessary. The Châlons maternité was transferred to Méry-sur-Seine, some $70 \mathrm{~km}$ south, where a suitable locale had been found. The following day was spent discharging those mothers and babies who were well enough to be sent home and organising the transport of bedding and furniture to Méry. The patients were then transferred to the new premises in cars making two trips each. By Sunday evening, all the patients were safely in bed in Méry, just in time for the birth of the first baby at the new hospital site.

A poste de secours was maintained in Châlons, for emergency cases. As the hospital was too unsafe at night, the prefecture arranged for a small enclosure to be reserved in one of the big champagne cellars under the Côte de Troyes. The maternity post was sectioned off by rudimentary wooden screens to afford some privacy from the gaze of the hundreds of individuals and assorted animals that were herded into to the pitch-dark caves. Pye described the scene:

Picture a rounded tunnel with three branches, each of them fifteen to eighteen feet wide. Up both sides of these, besides the huge wine barrels, rows and rows of beds touching each other-real beds with duvets and frilly pillows; improvised wooden beds, mattresses on boards, folding-chairs-every imaginable description of furniture on which to pass the night. Here one old lady has rigged up an umbrella over her bed, and fastened blankets and shawls round the sides of it - a very fair imitation of the four-poster her soul loves; next her is a poor old body severely upright on a wooden chair; then a comfortable double bed, with a father and mother and two or three children, all asleep. It is the most democratic of hotels, this. One is cheek-by-jowl with the world and his wife, and all his relatives, male and female, not to mention his dog and cat. ${ }^{78}$

The first of the babies to be born in the cave was delivered on the evening of 17 July. With the help of hot water bottles, mother and baby slept well and were ready for their

4 Edith Pye, Report on Maternité Anglaise, January 1918. (FHL, FEWVR.)

75 Edith Pye, Report on Maternité Anglaise, April 1918. (FHL, FEWVR).

76 Edith Pye, Report on Maternité Anglaise, June 1918. (FHL, FEWVR).

7 For details of this, see (Pye 1956).

78 (Fry 1927, pp. 64-65). 
journey down to the safety of Méry, the following afternoon. ${ }^{79}$ On the following night, a torpedo exploded about 20 yards away from the hospital, breaking every pane of glass and damaging the roof. The dispensary and one of the wooden huts were also destroyed, but, miraculously, no one was hurt. However, the remaining équipe had no option but to move into the children's home, where two small emergency wards were prepared. Volunteers from the staff then at Méry took it in turns to go up to Châlons, where the main work consisted of trying to clear up the mess in the maternity hospital and rescuing any remaining equipment. They also supervised the transport of maternity patients, as well as other sick and wounded between Châlons and Méry.

\section{The New Maison Maternelle de la Marne}

It was several months before the maternité was able to be reinstated in the newly refurbished quarters in Châlons. However, no more space could be spared in the asile - on the contrary, more space was required to be returned in order to accommodate the old people being sent back to Marne from the interior. As both the Friends and the French authorities were anxious that the FWVRC's work at Châlons remain on a permanent basis, the search was begun for a permanent site for the maternity hospital. Housing agents were visited, and advertisements were placed in the local press in vain attempts to find a suitable house for rent. As no appropriate premises could be found, it was decided to purchase a large piece of land on which there was a house in a fair state of repair that could be adapted for the purpose. The property eventually decided on was 47 Avenue Strasbourg (currently Charles de Gaulle) in the centre of Châlons.

Before the hospital could open its doors, however, there was a great deal of construction work to be done- a project managed by American Melvin Cawl. The purpose-built maternity hospital would comprise a pouponnière, crèche and quarters for staff, rooms suitable for the consultations des nourrissons, a laboratory, and a research room, as well as public and private (paying) wards. An automobile service would also be provided for bringing in and taking home patients. The idea was that this centre should coordinate all the maternity and child welfare work for the whole department. There would be a room in each town in which a weekly consulations des nourrissons could be held, and there would also be facilities for the diagnosis and treatment of cases of syphilis and gonorrhoea, particularly during pregnancy and lactation. If not viable as a midwifery training school, due to the lack of a faculty of medicine, the maternity hospital would give training as gardes couches, and the pupils could give their service in return for training.

The FWVRC decided that, in order to avoid state intervention in the running of the maternity hospital, the scheme for the future should be controlled by an independent joint departmental committee. The Conseil d'Administration would comprise representatives of local governing bodies and private subscribers and a representative of the Conseil Général de la Marne. In addition, three representatives of the FWVRC-Norman Brooks, Matilda Metford, and Edith Pye-made a total of 26 members. The present prefect, Monsieur Freminet, would become President and Léon Bourgeois, Honorary President. To aid a small staff, volunteers would be invited from among newly qualified nurses, future missionaries, and Friends who were keen to 'see something of French life in these conditions' ${ }^{80}$

The FWVRC would donate GBP 6000 a year for 10 years to the new maternity hospitala sum sufficient to guarantee the salaries of a trained staff for this period. Thus, it was hoped that the scheme would help expand the provision of maternity care and infant welfare in the spirit of the Friends and would serve as a model for others of the kind throughout France. ${ }^{81}$ This way, the Friends would also be helping in the work of reconstruction. The work had a truly international basis, and it was hoped that the maternité would keep alive the Quaker spirit of cooperation between members of different nations.

79 (Fry 1927, p. 65).

80 Edith Pye, Châlons report February 1919, 'Permanent scheme'. (FHL, FEWVR).

81 A similar scheme had been implemented earlier in the war in the Loire, but, with the exception of the directrice and two midwives, all the work was done by girls belonging to the Assistance Republique. 
Pye highlighted the religious spirit underlying its work. The Friends sought to give moral support to young mothers, especially young, unmarried girls, so that they might be encouraged to assume responsibility for the coming child instead of abandoning it to the Assistance Publique, as had been the case prior to the war. ${ }^{82}$ Curiously, in the official French records in the Archives Departamentales de la Marne, all the births at the maternite anglaise are recorded with the added detail of whether or not the baby was illegitimate-an apparently frequent occurrence that was never disclosed in the FWVRC's own official statistics. Monsieur Nicaud, inspector of the Assistance Publique, was particularly interested in the moral and educational aspects of the intended work and pledged his support, agreeing to form part of the Conseil d'Administration. ${ }^{83}$

The work would be carried out by the very capable French members of the staff who had already been working at the maternité for some time and were 'thoroughly imbued with the spirit and ideals of the Mission'. ${ }^{84}$ From early January 1918, French midwife Mademoiselle Merle had begun to play an important role in the hospital. ${ }^{85}$ When it was eventually handed over to the French, she took over from Pye as directrice. In the address she gave during the official handing-over ceremony in September 1919, while the hospital was still housed in the asile, Miss Merle vowed to keep up the standard of conscientious nursing of les Anglaises. She concluded:

All of us, the Committee, the staff and the patients know that the effort that has been made so far on the French side is nothing compared to the unfailing bounty with which the Society of Friends has forwarded the original scheme, first and foremost by the splendid gift of the house that is now rising fast, under the vigilant care of Melvin Cawl, also by the provisions they have made for the salaries of the staff, and by the priceless stocks they have left for our daily use, part of which will not be exhausted for several years [ ... ] We shall never forget how we came to exist and we shall always want to keep in close touch with you, both through the helpers that you will appoint to come to us, and the visitors whom we hope often to welcome at the Maison Maternelle de la Marne. ${ }^{86}$

During the four years and ten months that the hospital was under the care of the FWVRC, there were 981 births, and 1909 other infants and children were nursed in the pouponnière, altogether a total of 3789 persons had been sheltered and cared for at the institution. ${ }^{87}$ Pye was awarded the Cross of the Legion of Honour by the French government in recognition of all the work she and the Friends had done for the French people. It was really Clark who should have been given the honour, affirmed Pye, but Clark had left France before the war had ended and was already planning the next stage of her humanitarian work while recovering at home in England.

The costs of building work and equipment for the new hospital was estimated at about FF 1,500,000. Cawl produced a small booklet entitled Memorial Hospital of the Mission des Amis (in English and French), copies of which were distributed in France and between Friends in Philadelphia and London to give as much publicity as possible to the Châlons work and to encourage donations from various quarters. The French Field Reserve Fund, for example, contributed FF 250,000. This brought promised contributions by September 1920 to FF 1,350,000.00. ${ }^{88}$ Cawl describes the light and airy wards and modern bathrooms awaiting visitors to the new Maison Maternelle de la Marne. The hospital's pouponnière would have its own dining room and a toy-filled playroom, and for mothers, there would be a homely living room with a fire. Besides the large, well-ventilated wards and modern

Edith Pye, Chalons Report February 1919. Permanent scheme. (FHL, FEWVR)

Edith Pye, Suggestions for the continuance of the Chalons Maternity (undated). (FHL, FEWVR).

Edith Pye, Suggestions for the continuance of the Chalons Maternity (undated). (FHL, FEWVR).

ADM, Etat du personnel au 31 January 1918.

86 FRIENDS' EMERGENCY and WAR VICTIMS' RELIEF SOCIETY, 'Report be Mlle Jaqueline Merle on the Maternité at Chalons-sur-Marne'. (A talk delivered to Friends, undated.) (FHL, FEWVR).

87 (Fry 1927, p. 66).

88 Melvin A. Cawl, Report of work from 16 July to 1 September 1920. (FHL, FEWVR). 
operating room, there would be a sterilization room and storeroom and a salle de change where newborn babies could be changed, bathed, and weighed. Electric light would be fitted if finances allowed, and there would be a call bell at the side of each bed. There would also be a small isolation block, as well as separate blocks for the laundry and disinfecting room and a garage. Staff accommodation, comprising 'cosy and cheerful bedrooms' and modern bathrooms, was in the main building. Here, there would be a small library with French and English books, with comfortable armchairs and writing desks, so that the nurses could read and relax or write letters home. There was also a general recreation room for games and music, and outside, on the pleasant grounds, there was a tennis court. In total, the new building would accommodate 30 beds for mothers, 60 cradles for infants, and 30 beds for medical and domestic staff. ${ }^{89}$

Upon the eventual completion of the hospital, in March 1922, Esther Whitson, an American nursing assistant at the Châlons Maternity Hospital, wrote to Friends back home:

the rough barracks where we live were built by our boys in 1918. I was ushered into my barrack cold as Greenland with the windows open. There is one room here which is the nurses' living-room. It contains a long table, an awful piano, a big cupboard, a sewing machine, a small cot with three legs, a shelf of odd books and a stove- a welcome stove!

[ ... ] the new hospital [ ... ] is indescribable, beautiful beyond my expectations, and home-like [ ... ] The nursery and children's wards have fire-places and nursery rhymes and cows and cats and pictures all around the walls. ${ }^{90}$

\section{Conclusions}

Some 500 people attended the inauguration ceremony, including the present prefect, Monsieur Fréminet, and Léon Bourgeois, Honorary President of the Association. All lauded the magnificent and selfless work carried out by Friends (and, in particular, Pye) on behalf of the French people during the difficult years of war. Before the hospital was officially handed over to the French Committee, in the name of American and English Friends, Pye, guest of honour, also made a speech, in which she explained the purpose of the Quaker venture in Châlons and their hopes for the new hospital:

We want to teach the mothers how to care for their babies wisely; we want to help mothers in trouble and difficulty, and we want, at the same time, to teach educated French, English and American girls, as we have been doing, how to deal with babies and young children, so as to keep them healthy, so that they may in turn teach others. The international spirit will remain and will keep fresh the memory of 'Les Amis'. It will water the seeds of brotherhood sown in the time of France's distress, and may help them to continue to grow and flourish when her wounds are healed. ${ }^{91}$

The commemorative plaque remains to this day in the vestibule of the building at 47 Avenida General Charles de Gaulle, just as the Quaker star still adorns the gateposts outside. They were placed there at the express request of the French Committee in tribute to the Society of Friends and to symbolise the Quaker spirit in which work would be continued there for years to come.

The hospital flourished during the 1920s as births rose, stimulated by the state's postwar repopulation policy. Later, it faced the inevitable challenges of adapting to modern social and medical requirements, eventually ceasing to function as a maternity hospital on 31 December 1939. The premises are currently occupied by the Institut Médico Educatifle Carrefour d'Accompagnement Public Social. Fittingly, it provides the handicapped with the help and support they need to increase their possibilities of social integration.

\footnotetext{
89 For an excerpt from the booklet by Cawl, see: https:/ / www.afsc.org/sites/default/files/documents/1917\%20Memorial\%20Hospital.pdf (accessed on 17 November 2020).

90 Esther M. Whitson, excerpt of a letter published in the Quaker journal, The Friend, 30 March 1922.

91 Edith Pye, Suggestions for the continuance of the Chalons Maternity (undated). (FHL, FEWVR).
} 
The maternity work carried out in Châlons by Hilda Clark and Edith Pye and the many other volunteers epitomizes Quaker principles in action. The volunteers did what was most needed, whether they had planned to do it or not and whether or not it happened to be convenient for them at that particular moment in time. As well as preserving life, they brought the spirit of love and compassion to those (mostly women and children) in desperate need. What is more, they taught people how to help themselves, bringing renewed hope for a better future after the devastation and destruction of war.

Funding: This research was funded by the Spanish government, within the project 'Transnational humanitarian medicine and technological innovation in spaces of confinement 1870-1950' (PID 2019-104581 GB-100).

Institutional Review Board Statement: Not applicable.

Informed Consent Statement: Not applicable.

Data Availability Statement: Not applicable.

Conflicts of Interest: The author declares no conflict of interest.

\section{References}

Fry, Ruth. 1927. A Quaker Adventure: The Story of Nine Years' Relief and Reconstruction. New York: Frank-Maurice, Inc. Grant, Peter. 2014. Philanthropy and Voluntary Action in the First World War: Mobilizing Charity. New York: Routledge.

Martín-Moruño, Dolores. 2017. Tejiendo redes de cuidado. La compasión como conocimiento de las mujeres humanitarias en la guerra (1853-1945). In Al servicio de la salud humana. La historia de la medicina ante los retos del siglo XXI. Edited by Alfons Zarzoso and Jon Arrizabalaga. Ciudad Real: QL Printers.

McQuillan, Lisa. 2015. World War 1 relief and after: Hilda Clark. Quaker Connections, Number 64. March.

Palfreeman, Linda. 2018. 'The Friends' Ambulance Unit in the First World War. Religions 9: 165. [CrossRef]

Pearson, Arthur, and Gordon Pearson. 2015. Friends' Ambulance Unit in World War I and World War II. Dublin: Friends Historical Library Dublin.

Pye, Edith, ed. 1956. War and Its Aftermath: Letters from Hilda Clark, M.B., B.S. from France, Austria and the near East 1914-1924. London: Clare, Son \& Co. Ltd.

Religious Society of Friends. n.d. Whitefeather Diaries. Available online: http:/ / www.whitefeatherdiaries.org.uk/diary (accessed on 11 September 2020).

Roberts, Sian. 2014. Birmingham: Remembering 1914-18. Stroud: The History Press Ltd.

Rubinstein, David. 2015. A Quaker Dilemma: The Rowntree Family and the Great War 1914-1918. York: Quacks Books.

Storr, Katherine. 2010. Excluded from the Record: Women, Refugees and Relief 1914-29. Bern: Peter Lang. 